we determined when RDI should be ended and

\section{Deficit Irrigation to Control Vegetative Growth in Apple and Monitoring Fruit Growth to Schedule Irrigation}

\author{
Robert C. Ebel ${ }^{1}$, Edward L. Proebsting ${ }^{2}$, and Robert G. Evans ${ }^{\mathbf{3}}$ \\ Irrigated Agriculture Research and Extension Center, Washington State \\ University, Prosser, WA 99350
}

Additional index words. Malus domestica, cropload

\begin{abstract}
A standard fruit growth curve, used commercially as an aid to hand thinning, was compared to periodic volume measurements of apple fruit (Malus domestica Borkh. 'Delicious') subjected to early season regulated deficit irrigation (RDI) to determine when to end RDI, which is used to control vegetative growth and save water. RDI suppressed stem water potential, stomatal conductance, and fruit growth rate compared to the trickleand furrow-irrigated controls, which wetted about one-half and the entire soil volume, respectively. Full irrigation was restored to RDI trees by trickle and microsprinklers, which wetted about one-half and the entire soil volume, respectively, after terminal buds set. Stem water potential, stomatal conductance, and fruit growth rate of RDI trees increased to that of the controls, except for RDI/trickle trees, which had $80 \%$ the stomatal conductance of the other treatments. Fruit weight at harvest was affected by an interaction of irrigation treatment and cropload. RDI trees had similar or less vegetative growth and similar or higher yield efficiency than the controls. We recommend ending RDI before fruit growth declines below the standard curve.
\end{abstract}

Irrigation can be used to control the wetted root volume and plant water deficits of fruit trees in arid climates. The wetted root volume is less using trickle irrigation than using irrigation methods that wet the entire soil surface (Elfving, 1982). Water is applied to soil at one point through trickle emitters, which allows removal of available soil moisture by roots distant from the emitters. Roots in dry soil remain alive, but the bulk of water absorbed by roots occurs within the wetted soil volume under emitters. Plant water deficits can be induced in fruit trees by regulated deficit irrigation (RDI), which is the return of less water than trees are evapotranspiring (Boland et al., 1993; Mitchell et al., 1984).

Reducing the wetted root volume can suppress shoot growth (Richards and Rowe, 1977). Increasing plant water deficits can suppress shoot and fruit growth (Chalmers, et al., 1983; Lakso, 1985; Landsberg and Jones, 1981), with vegetative growth being more sensitive than fruit growth (Chalmers et al., 1986; Forshey and Elfving, 1989; Irving and Drost, 1987). Wetted root volume and plant water deficits interact in peach [Prunus persica $(\mathrm{L}$.

Received for publication 2 Dec. 1994. Accepted for publication 1 June 1995. Scientific paper no. 91-36, Washington State Univ. College of Agriculture Research Center, Pullman. This research was supported in part by a grant from the Washington Tree Fruit Research Commission. The cost of publishing this paper was defrayed in part by the payment of page charges. Under postal regulations, this paper therefore must be hereby marked advertisement solely to indicate this fact.

${ }^{1}$ Postdoctoral Fellow. Current address: Dept. of Horticulture, 102 Tyson Building, The Pennsylvania State Univ., University Park, PA 16802.

${ }^{2}$ Horticulturist.

${ }^{3}$ Agricultural Engineer.
Batsch] trees where deficit irrigation reduced stomatal conductance and shoot growth similarly, regardless of irrigated soil volume; in contrast, in nondeficit-irrigated trees, these factors were proportional to the irrigated soil volume (Proebsting et al., 1989). A strategy to use regulated water deficits and reduced wetted root volume, with appropriate timing, would be useful in arid apple-growing regions to promote partitioning of metabolites that would favor fruiting in apple trees. The same information would be useful for formulating irrigation strategies when water supplies are inadequate.

Fruit growth is the major limiting factor in developing a usable water management system for apple tree size control. RDI sometimes suppresses fruit growth. However, there is some evidence of enhanced fruit growth rate, above that of normally irrigated trees, when full irrigation is restored following the deficit period (Assaf et al., 1975; Chalmers et al., 1981, 1986; Cohen and Goell, 1988; Li et al., 1989; Mitchell et al., 1982, 1984, 1986). Monitoring apple fruit growth to determine when to end RDI would be useful to all desirable fruit sizing before harvest. Assaf et al. (1982) proposed using apple fruit growth as a basis for irrigation scheduling to produce a predictable discuss modifying irrigation scheduling to reduce vegetative growth additionally.

Standard fruit growth curves were developed and are available commercially to estimate fruit size at harvest as an aid to hand thinning (Batjer et al., 1957), because fruit growth is sensitive to cropload (Forshey and Elfving, 1989). In our study, RDI was used to produce midseason drought stress to restrict vegetative growth of apple trees. Based on the effect of irrigation treatment on fruit growth, fruit size at harvest; however, they did not then illustrate how standard fruit growth curves can be used to schedule RDI.

\section{Materials and Methods}

This study was conducted during the 1988 and 1989 growing seasons in an orchard near Prosser, Wash., that consisted of 'Redspur Delicious'/MM.106 as the main cultivar and 'Golden Delicious'/M.26 as the pollinizer. The trees were spaced $5.5 \times 5.5 \mathrm{~m}$. A $1.5-\mathrm{m}-$ wide strip within the tree row was maintained free of sod with herbicides. There was a wellestablished sod cover between rows that was mowed every 2 weeks. The sod became dormant by the end of June in trickle-irrigated plots.

The soil was a Warden fine sandy loam that was uniform down the profile. Field capacity (FC) was $\approx 28 \%$ by volume and permanent wilting percentage (PWP) was $\approx 8 \%$. Soil depth averaged $1.4 \mathrm{~m}$.

Average annual precipitation in this semiarid environment is $190 \mathrm{~mm}$, of which $50 \mathrm{~mm}$ falls during May through September (Kleingartner, 1977). Total evaporation from a U.S. Weather Bureau class "A" evaporation pan at the site was $\approx 800 \mathrm{~mm}$ from June through September in 1988 and 1989.

There were four treatments: furrow control, trickle control, RDI/microsprinkler, and $\mathrm{RDI} /$ trickle. The design contained three blocks. To prevent contamination of the other treatments by the furrow control, this treatment could not be randomized in what otherwise was a randomized block experiment. The furrow control consisted of the first two tree rows. Three furrow-irrigated trees adjacent to each block of the other three treatments were considered to be part of that block. Each of the other treatments consisted of nine trees per block grouped together in three rows with three trees per row, with the inner row the pollinizer.

Furrow irrigation was applied every 2 weeks to refill the entire soil volume to FC and thus minimize plant water deficits. Furrow irrigation was started 2 June 1988 and 6 June 1989 and was applied through harvest.

The trickle control trees received water equal to $100 \%$ of calculated evapotranspiration (ET) (James et al., 1988). ET was determined from an evaporation pan with a pan coefficient of 0.8 and adjusted by a crop coefficient. The crop coefficient was determined by the projected area of the canopy divided by the planting area and was changed on the 15 th of each month starting with 0.45 for April (full bloom was 22 Apr. 1988 and 20 Apr. 1989) then $0.7,0.85,0.9,0.85,0.7$, and 0.45 for May through October. Water applied assumed a field application efficiency of 0.9. Emitters for trickle treatments were spaced $1 \mathrm{~m}$ apart in a line and 0.5 to $1 \mathrm{~m}$ from the tree trunk. Irrigation starting and ending dates for the trickle control were the same as for the furrow control. Trickle irrigating at $100 \%$ ET kept $\approx 25 \%$ of the soil volume near FC.

RDI was imposed until terminal buds set in the RDI/trickle and RDI/microsprinkler plots. 
All water was withheld during RDI and restored on 8 July at $100 \%$ ET in the RDI/ trickle treatment in 1988. In the same treatment, in 1989, all water was withheld until 6 June and applied at 100\% ET from 6 to 30 June. However, shoot growth restarted, so water was again withheld. Trickle irrigation was restarted $15 \mathrm{Aug}$. and run continuously for 10 days to rewet about half the soil volume to FC; thereafter, it was run to replace $100 \%$ ET.

All water was withheld during RDI in the $\mathrm{RDI} /$ microsprinkler treatment in both years. Irrigation was restored on 8 July 1988 with daily 12-h application to keep soil moisture near FC and minimize plant water deficits. In 1989 , microsprinklers were run continuously for 5 days to bring the entire soil volume to FC; thereafter, they were run to replace $100 \%$ ET.

Trees were thinned to one fruit/spur by mid-June in 1988. However, because of a heavy cropload the previous year, the furrowirrigated trees had a cropload of $2.2 \mathrm{fruit} / \mathrm{cm}^{2}$ trunk cross-sectional area (TCA) $\pm \mathrm{SE}=0.1$, which was about half that of the other treatments, which averaged 5.4 fruit $/ \mathrm{cm}^{2} \mathrm{TCA} \pm \mathrm{SE}$ $=0.5$. Three cropload levels, which spanned the cropload range in 1988, were established in 1989. One tree per treatment in each block was hand-thinned by 25 June to two to three fruit/spur (which averaged 9.7 fruit $/ \mathrm{cm}^{2} \mathrm{TCA}$ $\pm \mathrm{SE}=0.6$ across irrigation treatments), one fruit/spur (4.7 fruit $\left./ \mathrm{cm}^{2} \mathrm{TCA} \pm \mathrm{SE}=0.3\right)$, or one fruit every fourth spur ( 1.5 fruit $/ \mathrm{cm}^{2} \mathrm{TCA}$ $\pm \mathrm{SE}=0.1$.

Soil moisture was measured every 2 to 4 weeks and at $15-\mathrm{cm}$ intervals down the profile to bedrock, 0.8 to $1.2 \mathrm{~m}$ below the surface. We used a neutron probe and PVC access tubes, with six tubes/plot in 1988 and 16 in 1989. Midday stem water potential $\left(\Psi_{\text {stem }}\right)$ was measured on covered leaves by the method of Garnier and Berger (1985), except with a 30min equilibration interval. Three leaves/tree were sampled between 1300 and $1600 \mathrm{HR}$. Leaf conductance $\left(\mathrm{g}_{1}\right)$ was measured with a steady-state porometer (LI-COR 1600; LICOR, Lincoln, Neb.) between 1300 and 1600 HR on five leaves/tree. Leaves selected for $\Psi_{\text {stem }}$ and $\mathrm{g}_{1}$ measurements were the largest basal leaves of current-season shoots, $1.5 \mathrm{~m}$ above the soil surface and fully exposed to the sun.

Fruit diameter of 10 tagged fruit/tree was measured every 7 to 14 days and fruit volume was estimated assuming spherical fruit. Fruit were harvested 18 Sept. 1988 and 9 Sept. 1989. Shoot lengths were measured after terminal buds were observed to have set. Trunk circumference was measured in autumn, 25 $\mathrm{cm}$ above the soil line.

Data were collected only on 'Delicious' and were analyzed as a block design using the GLM procedure of the statistical analysis system (SAS Institute, 1988). Three trees/treatment in each block were sampled. To separate irrigation from cropload effects, especially those of 1988, data from both years were combined in single analyses, and cropload (fruit/TCA) was used as a covariate in the analyses. A quadratic effect of cropload was tested in all models and was removed because it was nonsignificant. Cropload was usable as a covariate because the cropload levels were established before measurements were made. In analyses that included days from full bloom (DFFB), irrigation main effects were initially tested by year using a repeated measures analysis, but since the Huynh-Feldt (SAS Institute, 1988) test of compound symmetry was not significant in all analyses, data were reanalyzed as a split-plot, which combined years, included cropload as a covariate, and included appropriate interactions. In the absence of significant interactions, main effect means were separated using LSD.

\section{Results and Discussion}

Soil moisture approached PWP near the end of the RDI period, which produced midseason drought stress. $\Psi_{\text {stem }}$ and $g_{1}$ of the RDI trees reached their lowest values and were lower than those for the control trees at the end of the RDI period (Table 1). RDI about halved fruit growth rates compared to the controls. After full irrigation was restored, the irrigation $\times$ DFFB interaction was nonsignificant because $\Psi_{\text {stem }}, g_{\text {, }}$, and fruit growth rate of RDI trees were immediately brought to levels similar to those of the controls, as shown by similar irrigation main effect means. An exception was $\mathrm{g}_{1}$ of $\mathrm{RDI} /$ trickle-irrigated trees, which was brought up to $\approx 80 \%$ of the controls.

$\Psi_{\text {stem }}$ was not affected by cropload. The irrigation $\times$ cropload interaction was nonsignificant for $\mathrm{g}_{1}$ and fruit growth rate, indicating that slopes of all irrigation treatments were similar. The slopes of $g_{1}$ and fruit growth rate regressed against cropload were 0.0041 and -0.17 , respectively, at the end of the RDI period and 0.0004 and -0.11 , respectively, after full irrigation was restored.
RDI favored reproductive growth over vegetative growth by suppressing vegetative growth. RDI and the trickle control reduced the number and length of vigorous shoots compared to the furrow control (Table 2). Part of the greater growth of furrow-irrigated trees may have been related to their size before the experiment was begun, since TCA of these trees was $\approx 30 \%$ larger than for the trickle control and RDI trees, which had similar TCA. We expected that trees with larger structural frames would produce more shoots than smaller trees; additionally, the length of those shoots would not necessarily be related to tree size. RDI/trickle provided additional control of shoot length relative to the trickle control. Cropload did not affect shoot length, but there was an inverse relationship between the number of vigorous shoots and cropload (slope $=-1.2 \pm \mathrm{SE}=0.5$ ). Partitioning of growth was shifted from trunk cross-sectional area increase (TCAI) to yield when full irrigation was restored by microsprinklers, compared to the furrow control, but means of both of those treatments were similar to the means of the RDI/trickle and trickle control. Fruit yield (kg/tree) was similar across all treatments, so the improvement of partitioning by RDI was due to suppression of TCAI. Yield efficiency of the RDI treatments was similar to or better than that of the controls. There was a significant irrigation $\times$ cropload interaction on fruit weight at harvest (Fig. 1). Weight of fruit from furrow-irrigated trees was most strongly affected by cropload; RDI/ trickle was least affected by cropload, with the trickle control and RDI/trickle intermediate. Orchards with more vigorous vegetative growth than the trees in this study would likely benefit more from RDI.

Table 1. Stem water potential $\left(\Psi_{\text {stem }}\right)$, leaf conductance $\left(\mathrm{g}_{\mathrm{l}}\right)$, and fruit growth rate (FGR) of 'Delicious' apple trees the last week of the regulated deficit irrigation (RDI) period and the mean after full irrigation was restored.

\begin{tabular}{|c|c|c|c|c|c|c|}
\hline \multirow[b]{2}{*}{$\begin{array}{l}\text { Main effects } \\
\text { and significance }\end{array}$} & \multicolumn{3}{|c|}{ End of RDI period } & \multicolumn{3}{|c|}{$\begin{array}{c}\text { Mean after } \\
\text { irrigation restored }^{2}\end{array}$} \\
\hline & $\begin{array}{c}\Psi_{\text {stem }} \\
(\mathrm{MPa})\end{array}$ & $\begin{array}{c}\mathrm{g}_{\mathrm{l}} \\
\left(\mathrm{cm} \cdot \mathrm{s}^{-1}\right)\end{array}$ & $\begin{array}{c}\text { FGR } \\
\left(\mathrm{cm}^{3} \cdot \mathrm{day}^{-1}\right)\end{array}$ & $\begin{array}{c}\Psi_{\text {stem }} \\
(\mathrm{MPa})\end{array}$ & $\begin{array}{c}\mathrm{g}_{1} \\
\left(\mathrm{~cm} \cdot \mathrm{s}^{-1}\right)\end{array}$ & $\begin{array}{c}\text { FGR } \\
\left(\mathrm{cm}^{3} \cdot \mathrm{day}^{-1}\right)\end{array}$ \\
\hline \multicolumn{7}{|l|}{ Irrigation treatment } \\
\hline \multicolumn{7}{|l|}{ RDI } \\
\hline Trickle & $-2.09 \mathrm{~b}$ & $0.31 \mathrm{c}$ & $0.99 \mathrm{~b}$ & -1.67 & $0.51 \mathrm{~b}$ & 2.28 \\
\hline Microsprinkler & $-1.89 b$ & $0.42 \mathrm{~b}$ & $1.16 \mathrm{~b}$ & -1.46 & $0.60 \mathrm{a}$ & 2.57 \\
\hline \multicolumn{7}{|l|}{ Control } \\
\hline Trickle & $-1.14 \mathrm{a}$ & $0.62 \mathrm{a}$ & $2.48 \mathrm{a}$ & -1.58 & $0.60 \mathrm{a}$ & 2.64 \\
\hline Furrow & $-0.89 \mathrm{a}$ & $0.53 \mathrm{a}$ & $2.00 \mathrm{a}$ & -1.47 & $0.61 \mathrm{a}$ & 2.59 \\
\hline \multicolumn{7}{|l|}{ Year } \\
\hline 1988 & -1.45 & 0.64 & 1.49 & -1.72 & 0.77 & 3.17 \\
\hline 1989 & -1.52 & 0.41 & 1.71 & -1.19 & 0.48 & 2.00 \\
\hline \multicolumn{7}{|l|}{ F significance } \\
\hline Irrigation (I) & $* * *$ & $* *$ & $* * *$ & NS & $* * *$ & NS \\
\hline Year & NS & $* * *$ & NS & $* * *$ & $* * *$ & NS \\
\hline Cropload (C) & NS & $* *$ & $* * *$ & NS & $* * *$ & $* * *$ \\
\hline $\mathrm{I} \times \mathrm{C}$ & NS & NS & NS & NS & NS & NS \\
\hline DFFB & $---y$ & --- & --- & $* * *$ & $* * *$ & $* * *$ \\
\hline $\mathrm{I} \times \mathrm{DFFB}$ & --- & --- & --- & NS & NS & NS \\
\hline
\end{tabular}

${ }^{2}$ Days from full bloom (DFFB) were included in the model as a split plot over time.

y Not included in the statistical model since the dependent variable was only measured once.

Ns, **, *** Nonsignificant or significant at $P \leq 0.05$ or 0.01 , respectively. Mean separation in columns by LSD, $P \leq 0.05$. 
Table 2. Effect of irrigation treatment on 'Delicious' apple tree vegetative and reproductive growth. Data shown are the pooled means for 1988 and 1989.

\begin{tabular}{|c|c|c|c|c|c|}
\hline \multirow[b]{2}{*}{$\begin{array}{l}\text { Main effects } \\
\text { and significance }\end{array}$} & \multicolumn{2}{|c|}{ Shoot length } & \multirow{2}{*}{$\begin{array}{c}\text { Partitioning to } \\
\text { fruit component } \\
\text { Yield/TCAI } \\
\left(\mathrm{kg} \cdot \mathrm{cm}^{-2}\right)\end{array}$} & \multirow[b]{2}{*}{$\begin{array}{c}\text { Yield } \\
\text { (kg/tree) }\end{array}$} & \multirow{2}{*}{$\begin{array}{c}\text { Yield } \\
\text { efficiency } \\
\left(\mathrm{kg} / \mathrm{cm}^{2} \mathrm{TCA}^{\mathrm{y}}\right)\end{array}$} \\
\hline & $\begin{array}{l}\text { No. }>40 \\
\mathrm{~cm} \text { long }\end{array}$ & $\begin{array}{l}\text { Actual }^{2} \\
(\mathrm{~cm})\end{array}$ & & & \\
\hline \multicolumn{6}{|c|}{ Irrigation treatment } \\
\hline \multicolumn{6}{|l|}{ RDI } \\
\hline Trickle & $8 \mathrm{~b}$ & $28 \mathrm{c}$ & $13 \mathrm{ab}$ & 156 & $1.04 \mathrm{a}$ \\
\hline Microsprinkler & $7 \mathrm{~b}$ & $32 \mathrm{bc}$ & $16 \mathrm{a}$ & 172 & $1.12 \mathrm{a}$ \\
\hline \multicolumn{6}{|l|}{ Control } \\
\hline Trickle & $13 \mathrm{~b}$ & $36 \mathrm{~b}$ & $12 \mathrm{ab}$ & 154 & $1.02 \mathrm{a}$ \\
\hline Furrow & $25 \mathrm{a}$ & $42 \mathrm{a}$ & $10 \mathrm{~b}$ & 154 & $0.67 \mathrm{~b}$ \\
\hline \multicolumn{6}{|l|}{ Year } \\
\hline 1988 & 8 & 38 & 14 & 170 & 1.09 \\
\hline 1989 & 15 & 33 & 10 & 148 & 0.83 \\
\hline \multicolumn{6}{|l|}{ F significance } \\
\hline Irrigation (I) & $*$ & $* *$ & $*$ & NS & $* *$ \\
\hline Year & $* *$ & $* *$ & $* *$ & NS & $* * *$ \\
\hline Cropload (C) & $* *$ & NS & $--^{x}$ & --- & --- \\
\hline $\mathrm{I} \times \mathrm{C}$ & NS & NS & --- & --- & --- \\
\hline
\end{tabular}

${ }^{2}$ Of shoots $>20 \mathrm{~cm}$.

${ }^{\mathrm{y}} \mathrm{TCA}=$ trunk cross-sectional area (square centimeters), TCAI = trunk cross-sectional area increase (square centimeters).

${ }^{x}$ Not included in the statistical model.

Ns,****,****Nonsignificant or significant at $P \leq 0.10,0.05$, or 0.01 , respectively. Mean separation in columns by LSD, $P \leq 0.05$.

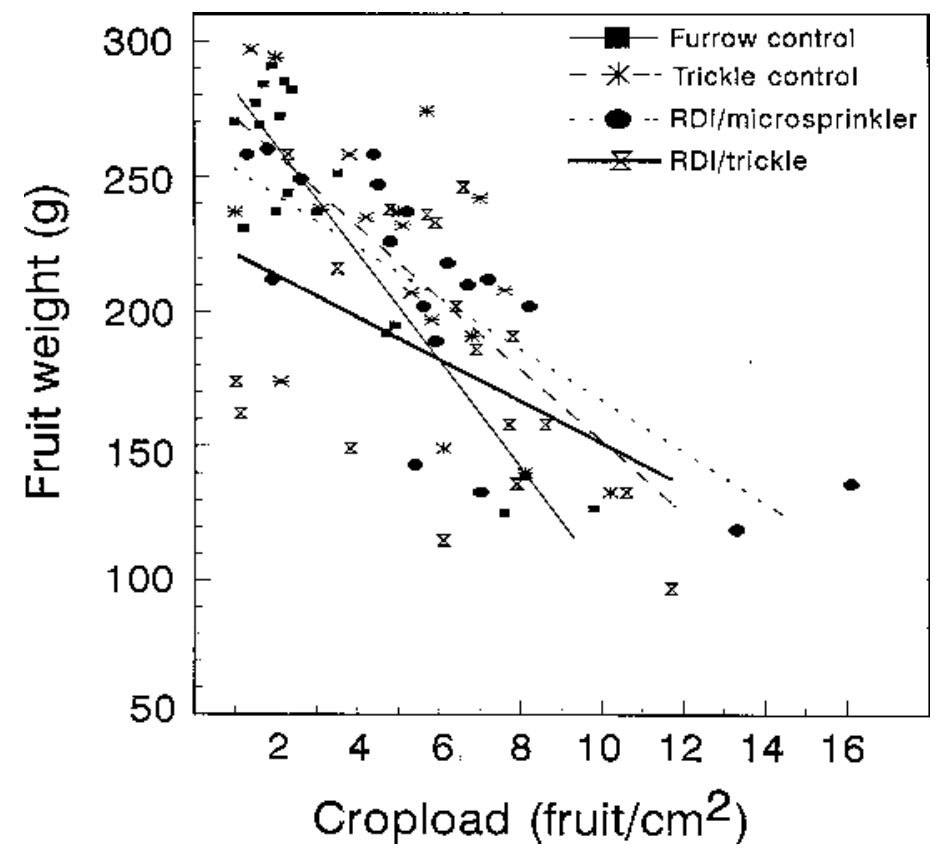

Fig. 1. Interaction of cropload and irrigation treatment on 'Delicious' fruit weight at harvest. Data for 1988 and 1989 are presented and each data point is of a single tree.

RDI and the trickle control treatments provided substantial water savings compared to furrow irrigation over the two years of the experiment. Average water applied for both years was $420,720,450$, and $825 \mathrm{~mm}$ for the $\mathrm{RDI} /$ trickle, RDI/microsprinkler, trickle control, and furrow control, respectively.

In using a standard growth curve to aid decisions regarding RDI, it is important to consider the additional effect of cropload on the rate of fruit growth. The 1989 fruit growth data, reflecting their clearly established three levels of cropload, best illustrates the comparison of a standard curve to actual fruit volume measurements (Fig. 2). Until the trees were thinned, fruit growth rate was suppressed and fruit volume was slightly below the standard curve. After thinning, the moderately cropped furrow and trickle controls had fruit volumes that generally followed the standard curve, although the curve for the trickle control was a little higher. Overcropping resulted in lower and undercropping in higher fruit volume than the standard curve. RDI suppressed fruit volume below the standard curve during RDI, except for fruit on the low-cropped, RDI/ microsprinkler trees. After full irrigation was restored, fruit volumes for the moderately cropped RDI/microsprinkler trees and the lowcropped RDI/trickle trees were similar to the volumes indicated by the standard curve at harvest.
In managing an RDI program to control vegetative growth, fruit volume measurements can be useful information in helping decide when to end RDI. Assuming that fruit growth resumes at a normal rate when full irrigation is restored, RDI should be ended before fruit volume falls below the standard curve. Thinning can compensate for water deficit.

RDI can be used to control vegetative growth and improve yield efficiency of apple trees. To ensure that volume per fruit at harvest is not reduced by RDI, we propose that regular measurements of fruit size be compared to size standards that are used in the industry to estimate at-harvest volume as a guide to hand-thinning requirements.

\section{Literature Cited}

Assaf, R., I. Levin, and B. Bravdo. 1975. Effect of irrigation regimes on trunk and fruit growth rates, quality and yield of apple trees. J. Hort. Sci. 50:481-493.

Assaf, R., I. Levin, and B. Bravdo. 1982. Apple fruit growth as a measure of irrigation control. HortScience 17:59-61.

Batjer, L.P., H.D. Billingsley, M.N. Westwood, and B.L. Rogers. 1957. Predicting harvest size of apples at different times during the growing season. Proc. Amer. Soc. Hort. Sci. 70:46-57.

Boland, A.M., P.D. Mitchell, P.H. Jerie, and I. Goodwin. 1993. The effect of regulated deficit irrigation on tree water use and growth of peach. J. Hort. Sci. 68(2):261-274.

Chalmers, D.J., G. Burge, P.H. Jerie, and P.D. Mitchell. 1986. The mechanism of regulation of 'Bartlett' pear fruit and vegetative growth by irrigation withholding and regulated deficit irrigation. J. Amer. Soc. Hort. Sci. 111:904-907.

Chalmers, D.J., P.D. Mitchell, and L. van Heek. 1981. Control of peach tree growth and productivity by regulated water supply, tree density, and summer pruning. J. Amer. Soc. Hort. Sci. 106:307-312.

Chalmers, D.J., K.A. Olsson, and T.R. Jones. 1983. Water relations of peach trees and orchards, $\mathrm{p}$. 197-232. In: T.T. Kozlowski (ed.). Water deficits and plant growth, vol. VII. Academic, New York.

Cohen, A. and A. Goell. 1988. Fruit growth and dry matter accumulation in grapefruit during periods of water withholding and after reirrigation. Austral. J. Plant Physiol. 15:633-639.

Elfving, D.C. 1982. Crop response to trickle irrigation, p. 1-48. In: D.P. Coyne, D. Durkin, and M.W. Williams (eds.). Horticultural reviews, vol. IV. AVI, Westport, Conn.

Forshey, C.G. and D.C. Elfving. 1989. The relationship between vegetative growth and fruiting in apple trees, p. 229-287. In: J.A. Barden, R.A. Larson, and L. Rappaport (eds.). Horticultural reviews, vol. XI. AVI, Westport, Conn.

Garnier, E. and A. Berger. 1985. Testing water potential in peach trees as an indicator of water stress. J. Hort. Sci. 60(1):47-56.

Irving, D.E. and J.H. Drost. 1987. Effects of water deficit on vegetative growth, fruit growth and fruit quality in Cox's Orange Pippin. J. Hort. Sci. 62(4):427-432.

James, L.G., J.M. Erpendbeck, D.L. Bassett, and J.E. Middleton. 1988. Irrigation requirements for Washington-Estimates and methodology. Coop. Ext., College of Agr. and Home Econ., Washington State Univ., Pullman. Ext. Bul. 1513.

Kleingartner, L.G. 1977. Data on weather from 1924-1976. Irrigated Agr. Res. and Ext. Ctr., Prosser, Wash. Ext. Bul. 858. 


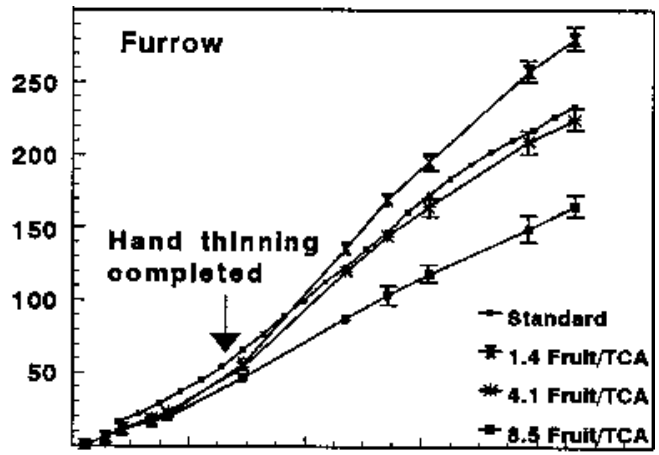

Lakso, A.N. 1985. The effects of water stress on physiological processes in fruit crops. Acta Hort. 171:275-290.

Landsberg, J.J. and H.G. Jones. 1981. Apple orchards, p. 419-469. In: T.T. Kozlowski (ed.). Water deficits and plant growth, vol. VI. Academic, New York.

Li, S.H., J.G. Huguet, P.G. Schoch, and P. Orlando. 1989. Response of peach tree growth and cropping to soil water deficit at various phenological stages of fruit development. J. Hort. Sci. 64(5):541-552.

Middleton, J.E., E.L. Proebsting, and S. Roberts. 1981. A comparison of trickle and sprinkler irrigation for apple orchards. Washington Agr. Expt. Sta. Bul. 0895.

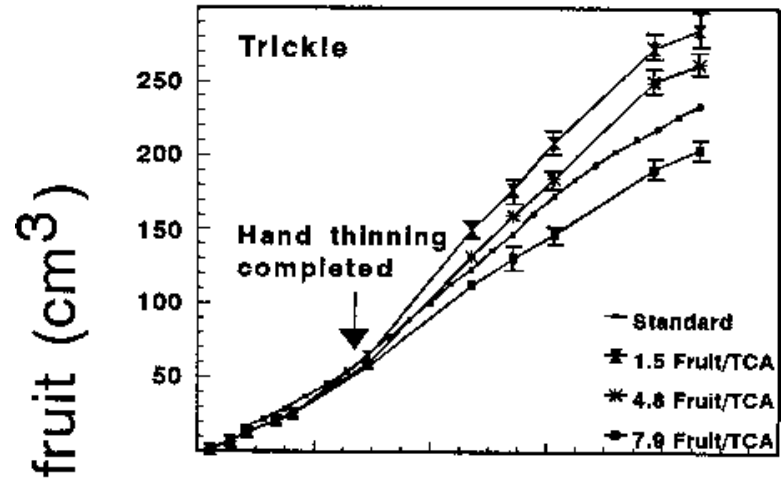

Mitchell, P.D. and D.J. Chalmers. 1982. The effect of reduced water supply on peach tree growth and yields. J. Amer. Soc. Hort. Sci. 197:853856.

Mitchell, P.D., D.J. Chalmers, P.H. Jerie, and G. Burge. 1986. The use of initial withholding of irrigation and tree spacing to enhance the effect of regulated deficit irrigation on pear trees. J. Amer. Soc. Hort. Sci. 111:858-861.

Mitchell, P.D., P.H. Jerie, and D.J. Chalmers. 1984. The effects of regulated water deficits on pear tree growth, flowering, fruit growth, and yield. J. Amer. Soc. Hort. Sci. 109:604-606.

Proebsting, E.L., P.H. Jerie, and J. Irvine. 1989. Water deficits and rooting volume modify peach tree growth and water relations. J. Amer. Soc. Hort. Sci. 114:368-372.

Proebsting, E.L., J.E. Middleton, and S. Roberts. 1977. Altered fruiting and growth characteristics of 'Delicious' apple associated with irrigation method. HortScience 12:349-350.

Richards, D. and R.N. Rowe. 1977. Effects of root restriction, root pruning and 6-benzylaminopurine on the growth of peach seedlings. Ann. Bot. 41:729-740.

SAS Institute. 1988. SAS/STAT user's guide, release 6.03. SAS Inst., Cary, N.C.

Scholander, P.F., J.T. Hammel, E.D. Bradstreet, and E.A. Hemmingsen. 1965. Sap pressure in vascular plants. Science 148:339-345.

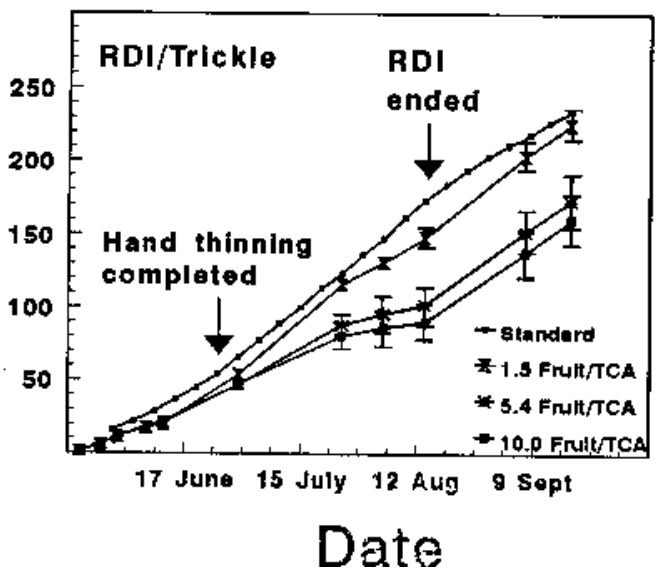

Fig. 2. Comparison of a standard fruit growth curve (Batjer et al., 1957) and 'Delicious' fruit growth in 1989 by irrigation treatment and at three croploads. Each data point is the mean of three trees, one from each block. Vertical bars are \pm SE of the mean; bars not shown are within the height of the data point symbol. 